\title{
Inhibitory Effect of ZnO-NPs and NF-CS-ZnO Nano- Hybrid Against Herpes Simplex Virus Type 1 Infection
}

\section{Mahya Abbasi}

Kerman University of Medical Sciences

\section{Zahra Arab-Bafrani}

Golestan University of Medical Sciences

Erfan Zabihi

Golestan University

Ali Mohammad Arabzadeh

Kerman University of Medical Sciences

\section{Amir Babaei}

Golestan University

Mohsen Sedaghat

Golestan University of Medical Sciences

Elham Mousavi ( $\square$ e.mousavi@kmu.ac.ir)

Kerman University of Medical Sciences

\section{Research Article}

Keywords: Herpes simplex virus, zinc oxide nanoparticles, nano-fibrillar chitosan-ZnO nano-hybrid.

Posted Date: May 6th, 2021

DOl: https://doi.org/10.21203/rs.3.rs-464644/v1

License: (a) This work is licensed under a Creative Commons Attribution 4.0 International License. Read Full License 


\section{Abstract}

Background: Since the viruses are intracellular parasite and their replication depends on the host cells, to develop a medication against the viral infections, some substances should be provided having no damage on the host's cells and tissue. Although the antiviral effects of zinc ion against the viral pathogens has been conspicuous, undesirably it shows a severe toxicity on the cells in cell culture and host tissues in animal models.

Methods: To optimize, zinc oxide nanoparticles with antiviral property at the lowest cell toxicity, nanofibrillar chitosan-ZnO nano-hybrid was synthesized and then, its inhibitory effect against the HSV replication was investigated in comparison to $\mathrm{ZnO}$ nanoparticles using plaque reduction and Real time PCR method.

Results: Although the infectivity of HSV-1 was reduced in initial steps of virus entry, the significant reduction of viral titer was observed in post exposure of Nano particles on HSV-1 infected cells. In contrary, no changes of viral load were identified in pre-incubation experiment, co-incubation of virus and nanoparticles prior to virus inoculation.

Conclusion: Nano-fibrillar CS could dramatically decrease the cell cytotoxicity of $\mathrm{ZnO}$, even though the antiviral effect of $\mathrm{ZnO}$ nanoparticles did not change. Nano hybrids appears to penetrate into the host cells and intracellularly inhibits the virus multiplication.

\section{Background}

Viruses are one of the main pathogens, which can cause severe diseases in human being (1). Although annually a wide range of drugs are offered to eradicate the viral microorganisms, due to the unique properties of viruses such as mutation's capability in generating new strains and particularly the emergence of drug resistant strains, most of available drugs are becoming useless $(2,3)$. Furthermore, the usage of some viral medications has been restricted as they cause devastating side effects on the individuals $(4,5)$. Therefore, there is a growing need to provide new, safe and effective drugs against viral infections.

In the recent years, by the growth of nanotechnology, a numerous variety of nanoparticles especially metal oxide nanoparticles have been developed to inhibit the infectivity of aboard range of human pathogens $(6,7)$. Amongst all, the application of zinc oxide nanoparticles (ZnO-NPs) as an antimicrobial agent has been more appealed as they represent several unique antimicrobial mechanisms such as the induction of oxidative stress and disruption of the bacterial membrane due to the accumulation of $\mathrm{ZnO}$ NPs $(8,9)$. Moreover, recent studies showed ZnO-NP has an efficient inhibitory activity against the several viral infections such as influenza, herpes simplex, rhinoviruses and corona viruses. It seems zinc ions can inhibit the virus's multiplication via interference with viral genome replication (10-12). 
In spite of high antiviral effect of Zno-NPs, scientific evidence shows that the ZnO-NP has a significant cytotoxicity on host cells $(13,14)$, thus the optimum concentration of this material in inhibition of viral replication must be accurately controlled. At the same time, some reports have shown that ZnO-NPs modification by natural polysaccharide materials such as cellulous, alginate, hyaluronic acid, starch and chitosan, can reduce ZnO-NPs cytotoxicity (15-17). Chitosan (CS) is known as a natural polysaccharide with remarkable properties such as biocompatibility and biodegradability. Furthermore, in some studies, antimicrobial activities of CS against the bacterial and fungal strains have been demonstrated (18). It has also been shown that the hybridization of nano-sized metal oxides and CS can improve the antibacterial properties $(19,20)$. Besides, it seems that CS can increase the permeability of nanoparticles into cells (21), which can be considered as an efficient option for developing antiviral drugs to inhibit the viral replication into cells. In the previous studies, hybridization of CS nanoparticles with antiretroviral drugs has improved the anti-HIV therapy as cell targeting efficiency increased by $92 \%$ compared to the conventional drug control (22). There is a possibility that CS not only can be utilized as a drug delivery candidate, but also has intrinsic antiviral effects (23).

It is established that CS can be produced in various morphologies by using different preparation processes, including natural powder, spherical and nano-structure (24). Among these morphologies, nanofibrillar's form can exhibit prominent properties in biomedical application due to the higher aspect ratio (25). Since viruses replicate into cells, this characteristic might increase the antiviral activity of ZnO-NPs. In the current study, antiviral effect of prepared ZnO-NPs and nano-fibrillar CS-ZnO (NF-CS-ZnO) nanohybrid was evaluated in the cell culture system. To this aim, Herpes simplex virus type 1(HSV1) replication, one of the members of herpesviridae family which is known as the leading cause of a broad spectrum of human disease including herpetic stomatitis, recurrent herpes labials, keratitis and encephalitis $(26,27)$ was targeted by synthetics nanoparticles.

\section{Methods}

\subsection{Materials}

Sodium hydroxide $(\mathrm{NaOH})(98 \%)$ and zinc acetate dehydrate were provided by Sigma-Aldrich Chemical Co. (USA). Nano-fibrilar-chitosan (NF-CS) powder was purchased from the Nano Novin Polymer Co. (Tehran, Iran). Other utilization solvents of analytical grade were provided by Mojallali Co. (Tehran, Iran).

\subsection{Synthesis of ZnO-NPs}

ZnO-NPs were synthesized within a simple co-precipitation method. Firstly, the $0.5 \mathrm{M}$ zinc acetate dehydrate solution was prepared in an Erlenmeyer flask at room temperature. Secondly, $0.5 \mathrm{M}$ solution of sodium hydroxide was treated to the zinc acetate dehydrate solution ( $\mathrm{PH}$ of the solution reached 7) under ultrasonic homogenizer condition (200 watts, 100\% amplitude, UP400St, Hielscher, Germany). The achieved light milky suspension was named ZnO-NPs. Finally, to remove the excess of zinc acetate and other impurities, the above suspension was washed several times using deionized water and ethanol and then dried using a vacuum oven at $60^{\circ} \mathrm{C}$ for $24 \mathrm{~h}$. 


\subsection{Preparation of NF-CS-ZnO nano-hybridnano-hybrid}

NF-CS-ZnO nano-hybrid was prepared within a facile co-precipitation method in room temperature. In the first stage, amount of nano-fibrilar CS powder $(0.3 \mathrm{gr})$ were dispersed in $0.5 \mathrm{M}$ zinc acetate dehydrate solution under ultrasonic homogenizer (200 watts, $100 \%$ amplitude) to obtain homogeneous suspension. In the second stage, $0.5 \mathrm{M}$ sodium hydroxide solution was treated to the prepared homogenous suspension in first stage under ultrasonic homogenizer condition (200 watts, $100 \%$ amplitude). Light milky suspension was achieved named NF-CS-ZnO nano-hybrid. Finally, to remove the excess of zinc acetate and other impurities, the above suspension was washed several times using deionized water and ethanol and then dried using a vacuum oven at $60^{\circ} \mathrm{C}$ for $24 \mathrm{~h}$.

\subsection{Characterization}

Field Emission Scanning Electron Microscopy (FE-SEM) model of ZEISS SIGMA VP-500, Germany was applied to investigate the morphology and size of ZnO-NPs and NF-CS-ZnO namo-hybrid. Functional group of ZnO-NPs and NF-CS-ZnO namo-hybridnano-hybridwere examined by fourier-transform infrared spectroscopy (FT-IR), model RX I, PerkinElmer, Inc., USA at a resolution of $4 \mathrm{~cm}^{-1}$.

\subsection{Virus and cell line}

HSV-1 strain and Vero cell line were gifted by Dr. Teimoori, assistance professor, from Hamadan University of Medical Sciences, Iran. To propagate virus, Vero cell line was cultured in Dulbecco's Modified Eagles Medium (DMEM, Gibco-Germany) plus 10\% fetal bovine serum (Gibco-Germany) and 1\% penicillin/streptomycin (Gibco-Germany) and incubated at $37^{\circ} \mathrm{C}$ with $5 \% \mathrm{CO} 2$. To determine virus's titer, plaque assay was performed and then viral particles with a multiplicity of infection $(\mathrm{MOI})$ of 0.01 were used in all the experiments.

\subsection{Determination of NPs cytotoxicity}

The methyl thiazolyl tetrazolium (MTT) assay and AO fluorescent staining were done to determine the possible cytotoxicity of NPs in Vero cell. In order to do MTT-assay, Vero cell monolayer were formed in a flat-bottomed 96 well plate after incubation at $37^{\circ} \mathrm{C}$ for $24 \mathrm{~h}$. Then various concentrations of NPs $(25$, $50,100,200 \mu \mathrm{g} / \mathrm{mL}$ ) was prepared in DMEM, $100 \mathrm{ul}$ of each dilution was added to each well and then the microplate was kept at $37^{\circ} \mathrm{C}$. After $24 \mathrm{~h}$ incubation, at first, cells were washed with PBS three times, then, $180 \mu \mathrm{L}$ of fresh DMEM and $20 \mu \mathrm{L}$ of MTT reagent $(5 \mathrm{mg} / \mathrm{mL})$ was added to each well, and the plate was incubated at $37{ }^{\circ} \mathrm{C}$ in the dark. After three hours, The MTT solution was discarded and $50 \mu \mathrm{L}$ of dimethyl sulfoxide (DMSO) was added to each well, and then the plate was gently shaken at room temperature for $10 \mathrm{~min}$. Finally, optical density was read at $570 \mathrm{~nm}$ by ELIZA reader. The percentage of survival cell was calculated according to the Mousavi et al (28). All experiment was done in triplicate.

For the AO fluorescent dye assay, Vero cell monolayer were seeded in 6-well tissue culture plates and incubated $\mathrm{ZnO}$-NPs and NF-CS-ZnO at $50 \mu \mathrm{gr} / \mathrm{ml}$ concentration. According to manufacturer's protocol AO 
florescent dye assay was performed $24 \mathrm{~h}$ after incubation. Briefly, cells were washed twice by PBS and then, $100 \mu \mathrm{g} / \mathrm{ml}$ AO fluorescent dye was added to each well. Finally, an inverted fluorescent microscope (Jeol JSM 6490) was used for the observation of alive cells within $30 \mathrm{~s}$.

\subsection{Assessment of NPs antiviral activity}

To experiment the effect of NPs in HSV replication's inhibition, three main stages of viral life cycle on Vero cells cultured in 24 well plate was evaluated. To explain briefly, in the pretreatment stage, Vero cell was exposed at the lowest toxic concentration of NPs for $4 \mathrm{~h}$. Then, cell monolayer was washed by PBS and infected by HSV1 strain (MOI: 0.01) for merely 1 hour. Unbound viruses were removed by washing and then fresh DMEM with $2 \%$ FBS was added to each well. In another stage named post infection, at first, the Vero cells was inoculated by virus strain and then, after 1 hour, cells were washed by PBS and finally cells were treated by different NPs. To evaluate, the direct virucidal activity of NPs, the pre incubation experiment was performed as a mixture of virus and nanoparticles was provided in a micro tube. The microtube was incubated on a shaker at room temperature for roughly 4 hours. The microtube was then centrifuged for $10 \mathrm{~min}$ at $4000 \mathrm{~g}$ and infection of cells was performed by 500ul of supernatant. Eventually, after $48 \mathrm{~h}$ incubation of the cells at $37^{\circ} \mathrm{C}$, the supernatant of each well was collected and tittered for infectivity of HSV1 on Vero cells by plaque reduction assay.

\subsection{Plaque reduction assay}

To determine the inhibitory effects of nanoparticles on HSV-1, plaque assays were performed on Vero cells. The cells were seeded onto 6-well culture plates in DMEM with $10 \%$ FBS to achieve nearly $95 \%$ of confluence. Serial dilution of supernatants collected in previous experiment were provided and then 500 $\mathrm{ml}$ of each dilution were added to each well. To allow virus attachment to cells, the plate was incubated at $37^{\circ} \mathrm{C}$ for $1 \mathrm{~h}$. Then, after washing cells by PBS, $3 \mathrm{ml}$ of $1.5 \%$ DMEM/agar was overlaid to each well. The plates were incubated for $72 \mathrm{~h}$ until the formation of plaques. To observe plaques, $1.5 \% \mathrm{DMEM} / \mathrm{agar}$ with Neutral red $0.01 \%$ was added to each well and plates incubated for $24 \mathrm{~h}$. Finally, the number of plaques in plate was counted and viral titer was calculated according to the following formula. A reduction in the number of plaques in each experiment was determined by comparison with a positive control.

*Viral titer formula:

No. of Plaques / (Dilution factor $x$ Volume of diluted virus $/$ well $)=\mathrm{pfu} / \mathrm{ml}$

\subsection{Quantitative Real-Time PCR assay}

To determine HSV viral load, Real-Time PCR assay was carried out in the following. Total RNA was extracted from supernatants collected in the interference experiments using the viral nucleic acid kit (Roche, Germany). The extracted RNA was then subjected to reverse transcription using the cDNA Synthesis Kit (Bio fact, Korea). The late gene UL27 (encoding glycoprotein gB) were determined by using 
Rotor-Gene Q instrument in a thermal profile of $95^{\circ} \mathrm{C}$ for $2 \min \left(1\right.$ cycle), $95^{\circ} \mathrm{C}$ for $30 \mathrm{~s}$, and $60{ }^{\circ} \mathrm{C}$ for $15 \mathrm{~s}$ (35 cycles, respectively) (29). The transcription levels of total RNA in each sample were normalized against the GAPDH gene. Relative quantification was carried out based on the $2^{-\triangle \Delta C T}$ threshold cycle method.

\subsection{Statistical analysis}

ANOVA and Least Significant Difference (LSD) test was done to compare viral titer reduction in each experiment. The $P$ value of $<0.05$ was considered statistically significant. All the data are given as the mean \pm SD. SPSS software, version 22 was run to do all calculations.

\section{Results}

\subsection{Characterization of prepared ZnO-NPs and NF-CS-ZnO nano-hybrid}

FE-SEM micrographs of the synthesized ZnO-NPs and NF-CS-ZnO nano-hybrid are shown in Fig.1 (a, b). According to Fig.1a, the successful formation of ZnO-NPs with the spherical morphology at around 50-70 $\mathrm{nm}$ was illustrated. Moreover, it can be clearly seen that in the specimen of prepared NF-CS-ZnO nanohybrid (Fig. 1b), the spherical ZnO-NPs have favorably covered the surface of NF-CS. Importantly, it seems that NF-CS act as a steric hindrance to prevent aggregation of ZnO-NPs. Figure 1c shows the FT-IR spectrums of the ZnO-NPs and NF-CS-ZnO nano-hybrid. In the case of pure ZnO-NPs, there are two characteristic peaks at about $467 \mathrm{~cm}^{-1}$ and $3361 \mathrm{~cm}^{-1}$ which are related to the stretching modes of $\mathrm{Zn}-\mathrm{O}$ and - $\mathrm{OH}$ groups of ZnO-NPs, respectively. For the specimen of NF-CS-ZnO nano-hybrid, the observed peaks at around $3420 \mathrm{~cm}^{-1}, 2921 \mathrm{~cm}^{-1}, 2851 \mathrm{~cm}^{-1}, 1572 \mathrm{~cm}^{-1}$ and $1046 \mathrm{~cm}^{-1}$ are assigned to the stretching vibrations of $-\mathrm{OH},-\mathrm{CH} 3,-\mathrm{CH} 2,-\mathrm{NH} 2,-\mathrm{C}-\mathrm{O}-\mathrm{C}$ - groups of NF-CS, respectively. Additionally, two strong peaks at around $466 \mathrm{~cm}^{-1}$ and $826 \mathrm{~cm}^{-1}$ were observed, indicating the stretching mode of $0-\mathrm{Zn}-0$ groups. Similar results have been reported by other researchers to form the ZnO-NPs on CS successfully $(30,31)$.

\subsection{Nanoparticles and Nano hybrids 's toxicity on cell survival}

NPs cytotoxicity against the Vero cells was analyzed by MTT assay and AO fluorescent staining. The results of MTT assay showed that the viability of cells significantly decreased to $40 \%$ when Vero cells was treated by $50 \mu \mathrm{g} / \mathrm{ml}$ of ZnO-NPs. However, Vero cells exposed with 25,50 and $100 \mu \mathrm{g} / \mathrm{mL}$ of ZnO-CSNPs showed the cell survival roughly 90,80 and $65 \%$ respectively (Fig. 2 a). The microscopic assay on normal cells in comparison with Vero cells treated by nanoparticles also indicated that toxic concentration of ZnO-NPs has lead cells becoming tiny, round and detached from the bottom plate (Fig.2.b). Accordingly, AO florescent dye results showed that the population of viable cells (green cells) incubated with ZnO-CS-NPs was similar to the control group while the population of viable cells in $\mathrm{ZnO}$ NPs group was significantly reduced (Fig. 2.c). Therefore, based on the obtained results, the optimum concentration of $25 \mu \mathrm{g} / \mathrm{ml}$ of ZnO-NPs and $50 \mu \mathrm{g} / \mathrm{ml}$ of ZnO-CS-NPs was applied for the all experiments. 


\subsection{Antiviral activity of the ZnO-NPs and ZnO-CS-NPs}

To evaluate antiviral effect of nanoparticles in vitro, three main experiments were designed as explained in the method section and then viral load was assayed by plaque reduction method. As illustrated in Fig.3a, b, both ZnO nanoparticles and ZnO-CS nano-hybrids could significantly inhibit the viral replication in the post and pretreatment stages as the viral titer substantially decreased in comparison with the control group. The reduction of cytopathic effects of infected cells in different experiments can also be observed in Fig. 4. Amongst three stages, no remarkable changes were observed in viral infectivity in pre incubation stage.

\subsection{Real time PCR results}

To confirm, the viral titer reduction in the presence of nanoparticles, the relative quantity of HSV genome in Vero cells exposed by nanoparticles (treat group) compared with HSV infected cells (control group) using real time PCR. As shown in Fig.5, the copy number of HSV gene B in the pretreatment and post infection groups was significantly declined $(P=0.02)$, while no change was observed on pre incubation experiment.

\section{Discussion}

Although the effect of zinc ion against a wide range of viral pathogens has been proven since 1967, the utilization of it as a viral medication has been restricted as it is quite toxic for host cells (29).

In the current study, to optimize, Zno nanoparticles with antiviral property and the least toxicity on host cells, Zno NPs coated with nanofibers chitosan was offered to investigate their inhibitory effect against HSV replication in Vero cells. As figure three and five shown, both Zno and Zno-CS nanoparticles could significantly inhibit viral replication in the post and pretreatment stages as the viral titer substantially decreased in compared with group control. Interestingly though, Zno-Cs nanoparticles has shown a lower toxicity on Vero cells confirming that surface chitosan of nanoparticles plays a key role in reduction of cell cytotoxicity on Vero cells (Fig. 2).

As the results shows (Fig. 3,5), it seems that nanoparticles are not able to directly trap and destroy the structure of viral particles, as the declining of viral titer was no significant in the pre incubation assay. In fact, in this stage, nanoparticles were treated by HSV virus in a free cell system at four hours and then the exposed HSV particles was inoculated into Vero cell line. This experiment might obviously support this idea that zinc oxide nanoparticles has no physical interaction by HSV particles and as a result, they do not have efficient direct virucidal activity. Nevertheless, in the pretreatment experiment and, particularly, in the post infection stage, the reduction of viral infectivity was vividly observable (Fig. 3,5). To explain this finding, the antiviral activity of zno nanoparticles are more likely to be intracellularly exerted. As the dimension of nanoparticles are very small nearly $100 \mathrm{~nm}$, they can effectively penetrate into the cells and interfere with viral replication. In consistent with our findings, a few previous studies also showed that zinc ions could block viral polymerase activity or hinder viral polyproteins processing (10-12). Although, 
the viral titer also has declined in the pretreatment experiment, the reduction was more significant in post infection experiment. The aim of pretreatment assay was showing the nanoparticles capability in blocking cellular receptors in term of hindrance of virus entry. However, it seems nanoparticles are more capable to enter cells and intracellularly inhibit viral replication instead of involving in the virus attachment stage to cell receptors.

\section{Conclusions}

In conclusion, although zinc oxide has a considerable cytotoxicity on host cells, we could optimize it by creating zno nanoparticles coated by chitosan, which have shown notable antiviral activity against HSV virus. Furthermore, the present results indicate that the inhibitory mechanism exerted by nanoparticles is more probably in the result of interference of NPs with one of the viral replication stages into cells. Although it can be promising to use zinc oxide-cs nanoparticle in treatment of viral diseases, more experiments need to investigate the antiviral activity of such nanoparticles against different types of viral pathogens in vitro and in vivo as well.

\section{Abbreviations}

Herpes simplex type (HSV), Zinc Oxide (ZnO), Chitosan (CS), Nanoparticles (NP), human immunodeficiency virus (HIV), nano-fibrillar (NF), Field Emission Scanning Electron Microscopy (FE-SEM), methyl thiazolyl tetrazolium (MTT), Polymerase chain reaction ( PCR), dimethyl sulfoxide (DMSO)

\section{Declarations}

\section{Ethics approval and consent to participate}

The study was approved by the Ethical Committee of Kerman University of Medical Sciences (IR.KMU.REC.1398.730)

\section{Consent for publication}

Not applicable.

\section{Availability of data and materials}

The datasets used and/or analyzed during the current study available from the corresponding author on reasonable request

\section{Competing Interests}

The authors have declared that there are no conflict of interest.

\section{Funding}


This study was supported by Kerman University of medical science, Kerman, Iran (grant number 98000153).

\section{Authors' contributions}

$M E$ and $A B Z$, and $B A$ designed the research. $M E, A M$, and ZE performed the experiments. $A B Z, M E$, and $A M$, and $Z E$ contributed to analysis and interpretation of data. ME, AM and ABZ, SM wrote the manuscript. All authors reviewed the manuscript.

\section{ACKNOWLEDGMENTS}

The authors are highly thankful to all technicians who provided support during the course of research.

\section{References}

1. Woolhouse M, Scott F, Hudson Z, Howey R, Chase-Topping M. Human viruses: Discovery and emeraence. Philos Trans R Soc B Biol Sci. 2012;367(1604):2864-71.

2. Hussain M, Galvin HD, Haw TY, Nutsford AN, Husain M. Drug resistance in influenza a virus: The epidemiology and management. Infect Drug Resist. 2017;10:121-34.

3. Lontok E, Harrington P, Howe A, Kieffer T, Lennerstrand J, Lenz O, et al. Hepatitis C virus drug resistance-associated substitutions: State of the art summary. Hepatology. 2015;62(5):1623-32.

4. Spengler U, Lichterfeld M, Rockstroh JK. Antiretroviral drug toxicity - A challenge for the hepatologist J Hepatol. 2002;36(2):283-94.

5. Calmy A, Hirschel B, Cooper DA, Carr A. A new era of antiretroviral drug toxicity. Antivir Ther. 2009;14(2):165-79.

6. Azam A, Ahmed AS, Oves M, Khan MS, Habib SS, Memic A. Antimicrobial activity of metal oxide nanoparticles against Gram-positive and Gram-negative bacteria: a comparative study. Int J Nanomedicine. 2012;7:6003.

7. Ren G, Hu D, Cheng EWC, Vargas-Reus MA, Reip P, Allaker RP. Characterisation of copper oxide nanoparticles for antimicrobial applications. Int J Antimicrob Agents. 2009;33(6):587-90.

8. Espitia PJP, Soares N de FF, Coimbra JS dos R, de Andrade NJ, Cruz RS, Medeiros EAA. Zinc Oxide Nanoparticles: Synthesis, Antimicrobial Activity and Food Packaging Applications. Food Bioprocess Technol. 2012;5(5):1447-64.

9. Pasquet J, Chevalier Y, Couval E, Bouvier D, Noizet G, Morlière C, et al. Antimicrobial activity of zinc oxide particles on five micro-organisms of the Challenge Tests related to their physicochemical properties. Int J Pharm. 2014;460(1):92-100.

10. Read SA, Obeid S, Ahlenstiel C, Ahlenstiel G. The Role of Zinc in Antiviral Immunity. Adv Nutr. 2019;10(4):696-710.

11. Ghaffari H, Tavakoli A, Moradi A, Tabarraei A, Bokharaei-Salim F, Zahmatkeshan M, et al. Inhibition of H1N1 influenza virus infection by zinc oxide nanoparticles: another emerging application of 
nanomedicine. J Biomed Sci. 2019;26(1):1-10.

12. Gurunathan S, Qasim M, Choi Y, Do JT, Park C, Hong K, et al. Antiviral potential of nanoparticles can nanoparticles fight against coronaviruses? Nanomaterials. 2020;10(9):1-29.

13. Borovanský J, Riley PA. Cytotoxicity of zinc in vitro. Chem Biol Interact. 1989;69(2):279-91.

14. Igic PG, Lee E, Harper W, Roach KW. Toxic Effects Associated With Consumption of Zinc. Mayo Clin Proc. 2002;77(7):713-6.

15. Shahmohammadi Jebel F, Almasi H. Morphological, physical, antimicrobial and release properties of ZnO nanoparticles-loaded bacterial cellulose films. Carbohydr Polym. 2016;149:8-19.

16. Saad AHA, Azzam AM, El-Wakeel ST, Mostafa BB, Abd El-latif MB. Removal of toxic metal ions from wastewater using ZnO Chitosan core-shell nanocomposite. Environ Nanotechnology, Monit Manag. 2018;9:67-75.

17. Chia SL, Leong DT. Reducing ZnO nanoparticles toxicity through silica coating. Heliyon. 2016;2(10):e00177.

18. Qi L, Xu Z, Jiang X, Hu C, Zou X. Preparation and antibacterial activity of chitosan nanoparticles. Carbohydr Res. 2004;339(16):2693-700.

19. Majidi HJ, Babaei A, Bafrani ZA, Shahrampour D, Zabihi E, Jafari SM. Investigating the best strategy to diminish the toxicity and enhance the antibacterial activity of graphene oxide by chitosan addition. Carbohydr Polym. 2019;225:115220.

20. Zabihi E, Babaei A, Shahrampour D, Arab-Bafrani Z, Mirshahidi KS, Majidi HJ. Facile and rapid in-situ synthesis of chitosan-ZnO nano-hybrids applicable in medical purposes; a novel combination of biomineralization, ultrasound, and bio-safe morphology-conducting agent. Int J Biol Macromol. 2019;131:107-16.

21. Indumathi MP, Saral Sarojini K, Rajarajeswari GR. Antimicrobial and biodegradable chitosan/cellulose acetate phthalate/ZnO nano composite films with optimal oxygen permeability and hydrophobicity for extending the shelf life of black grape fruits. Int J Biol Macromol. 2019;132:1112-20.

22. Dev A, Binulal NS, Anitha A, Nair S V, Furuike T, Tamura H, et al. Preparation of poly (lactic acid)/chitosan nanoparticles for anti-HIV drug delivery applications. Carbohydr Polym. 2010;80(3):833-8.

23. Kulikov SN, Chirkov SN, Il'ina A V, Lopatin SA, Varlamov VP. Effect of the molecular weight of chitosan on its antiviral activity in plants. Appl Biochem Microbiol. 2006;42(2):200-3.

24. Kalantari K, Afifi AM, Jahangirian H, Webster TJ. Biomedical applications of chitosan electrospun nanofibers as a green polymer - Review. Carbohydr Polym. 2019 Mar;207:588-600.

25. Almasi H, Jafarzadeh P, Mehryar L. Fabrication of novel nanohybrids by impregnation of CuO nanoparticles into bacterial cellulose and chitosan nanofibers: Characterization, antimicrobial and release properties. Carbohydr Polym. 2018;186:273-81. 
26. Brugha R, Keersmaekers K, Renton A, Meheus A. Genital herpes infection: a review. Int J Epidemiol. 1997 Aug;26(4):698-709.

27. Looker KJ, Garnett GP. A systematic review of the epidemiology and interaction of herpes simplex virus types 1 and 2. Sex Transm Infect. 2005;81(2):103-7.

28. Mousavi E, Makvandi M, Teimoori A, Ataei A, Ghafari S, Samarbaf-Zadeh A. Antiviral effects of Lactobacillus crispatus against HSV-2 in mammalian cell lines. $J$ Chinese Med Assoc. 2018;81(3):262-7.

29. Fani M, Khodadad N, Ebrahimi S, Nahidsamiei R, Makvandi M, Teimoori A, et al. Zinc Sulfate in Narrow Range as an In Vitro Anti-HSV-1 Assay. Biol Trace Elem Res. 2020;193(2):410-3.

30. Shafiq M, Yasin T, Aftab Rafiq M, Shaista. Structural, thermal, and antibacterial properties of chitosan/ZnO composites. Polym Compos. 2014 Jan;35(1):79-85.

31. $P$ MR, Muraleedaran $K$, Mujeeb VMA. Applications of chitosan powder with in situ synthesized nano ZnO particles as an antimicrobial agent. Int J Biol Macromol. 2015 Jun;77:266-72.

32. Kumel G, Schrader S, Zentgraf H, Daus H, Brendel M. The mechanism of the antiherpetic activity of zinc sulphate. J Gen Virol. 1990;71(12):2989-97.

33. Krenn BM, Gaudernak E, Holzer B, Lanke K, Van Kuppeveld FJM, Seipelt J. Antiviral Activity of the Zinc lonophores Pyrithione and Hinokitiol against Picornavirus Infections. J Virol. 2009;83(1):58-64.

34. Kümel G, Schrader S, Zentgraf H, Brendel M. [Therapy of banal HSV lesions: molecular mechanisms of the antiviral activity of zinc sulfate]. Hautarzt. $1991 \mathrm{Jul} ; 42(7): 439-45$.

35. Benhabiles MS, Salah R, Lounici H, Drouiche N, Goosen MFA, Mameri N. Antibacterial activity of chitin, chitosan and its oligomers prepared from shrimp shell waste. Food Hydrocoll. 2012;29(1):4856 .

\section{Figures}


a

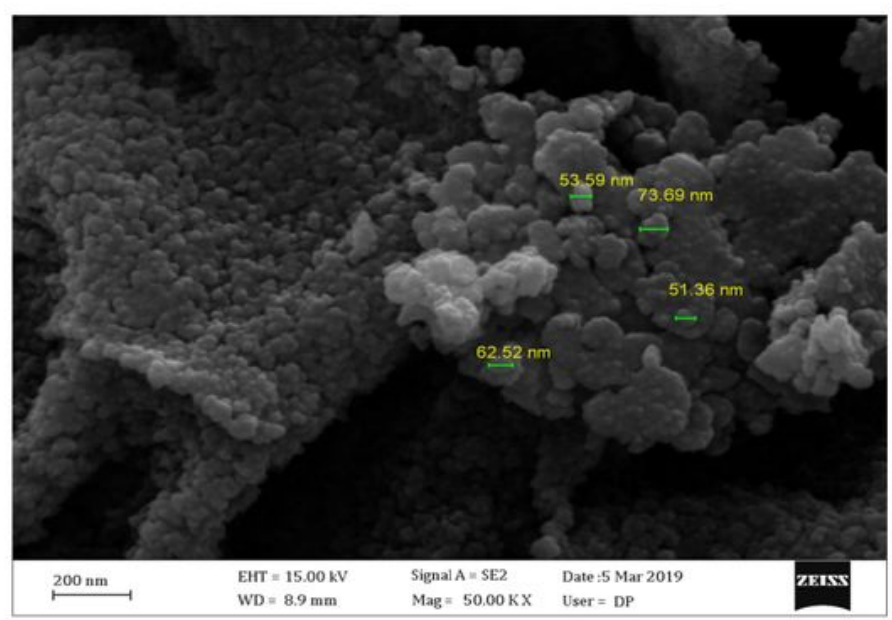

b
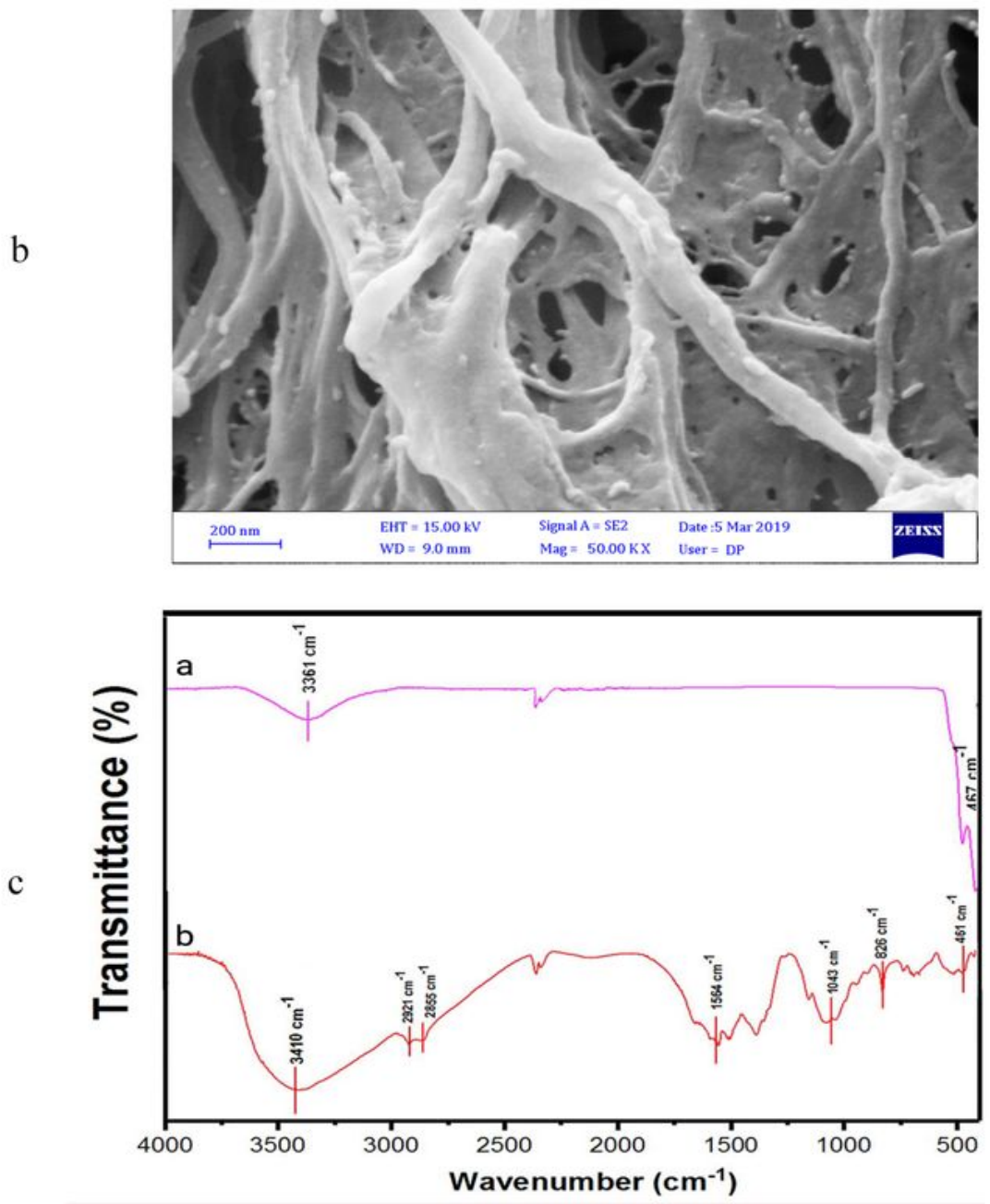

Figure 1

FE-SEM micrograph of a) ZnO-NPs, b) NF-CS-ZnO nano-hybridand c) FT-IR of synthesized samples. 

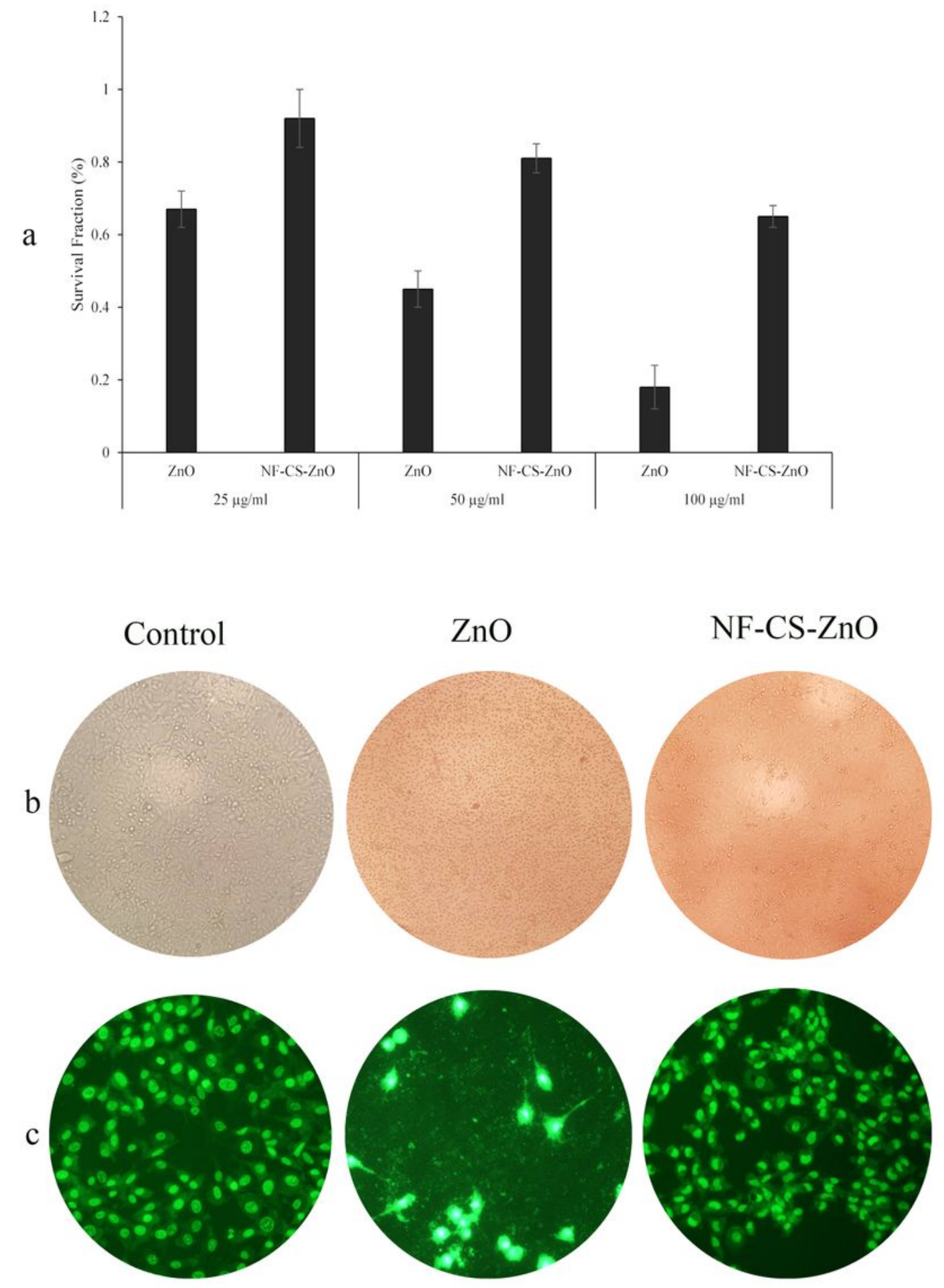

Figure 2

a) Cytotoxicity effect of ZnO-NPs and NF-CS-ZnO nano-hybrid on Vero cell line. Cell viability was identified by MTT assay after $24 \mathrm{~h}$. b) Microscopy and c) AO florescent dye images of cells exposed by nanoparticles at $50 \mu \mathrm{gr} / \mathrm{ml}$ concentration 


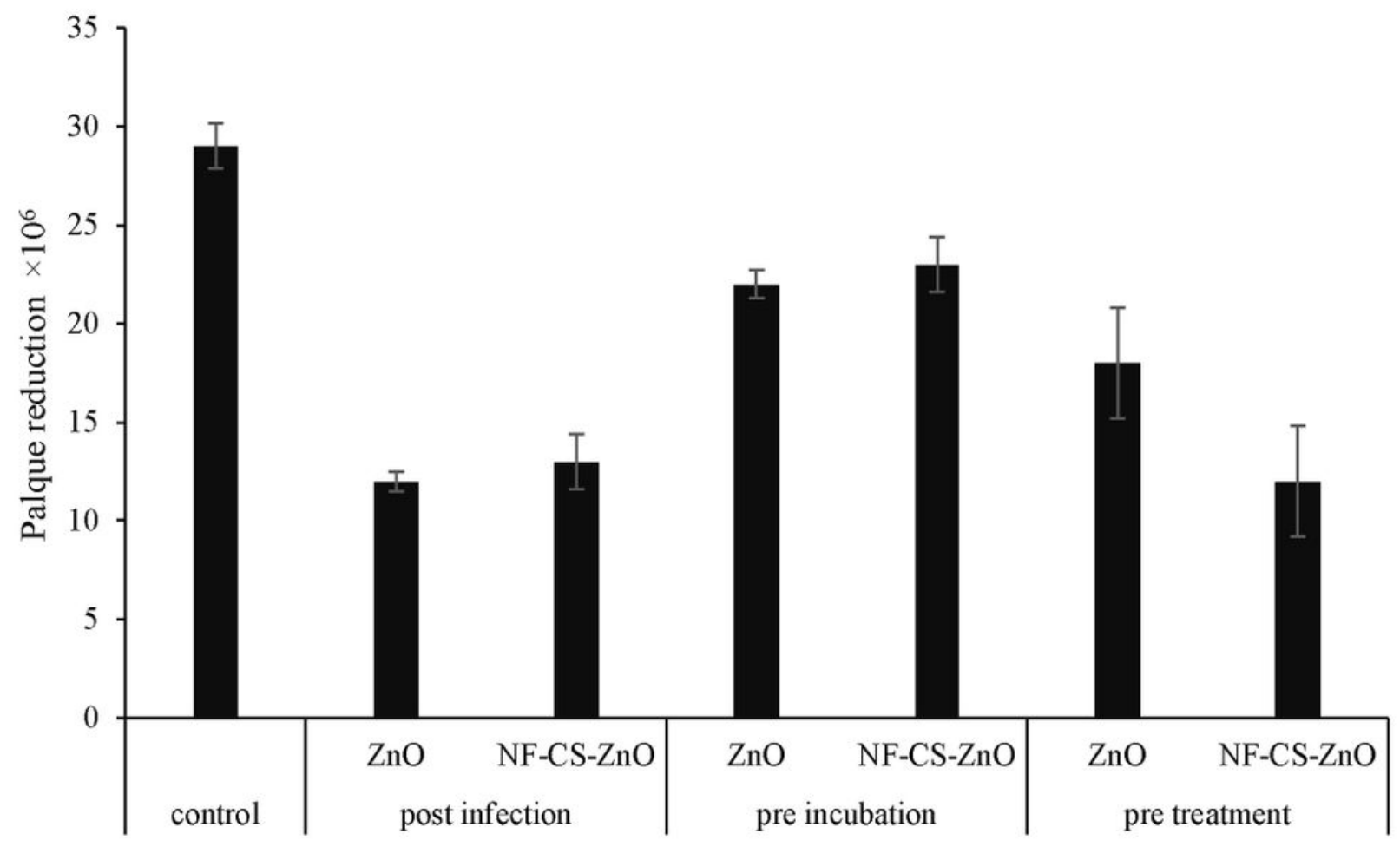

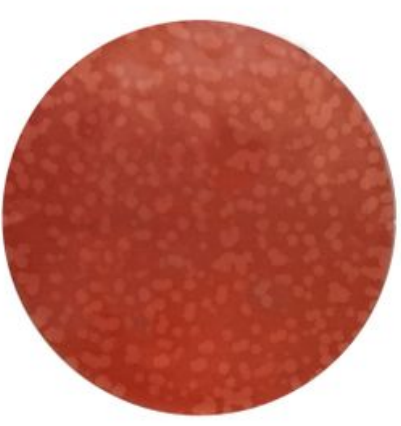

Control

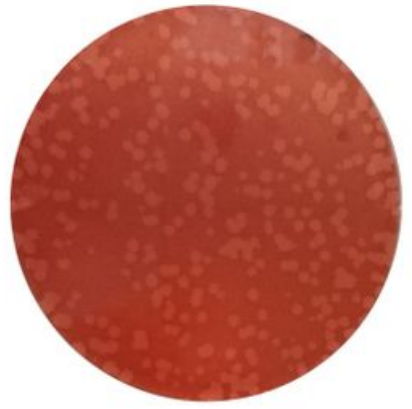

Pre incubation

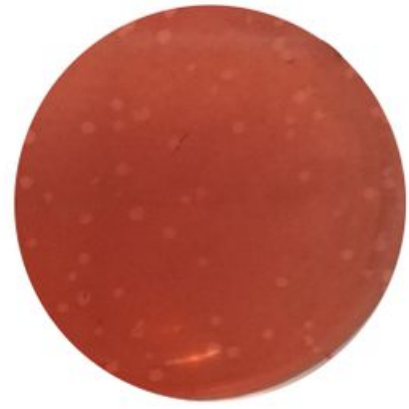

Pre treatment

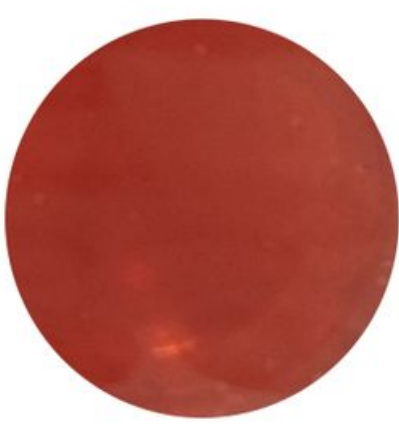

Post infection

Figure 3

a) Inhibition of HSV-2 replication by nanoparticles. The reduction of the virus titer measured by a plaque assay. The results were mean \pm standard deviations from three independent experiments. b) The reduction of plaques in different stages. 


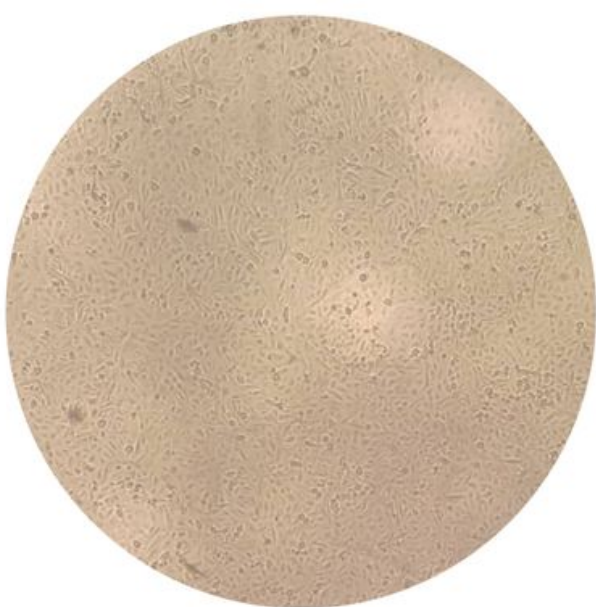

Negative control

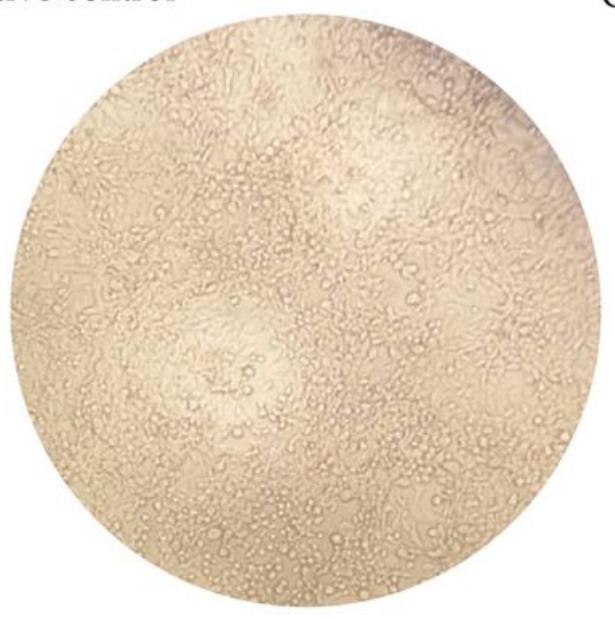

Pre treatment

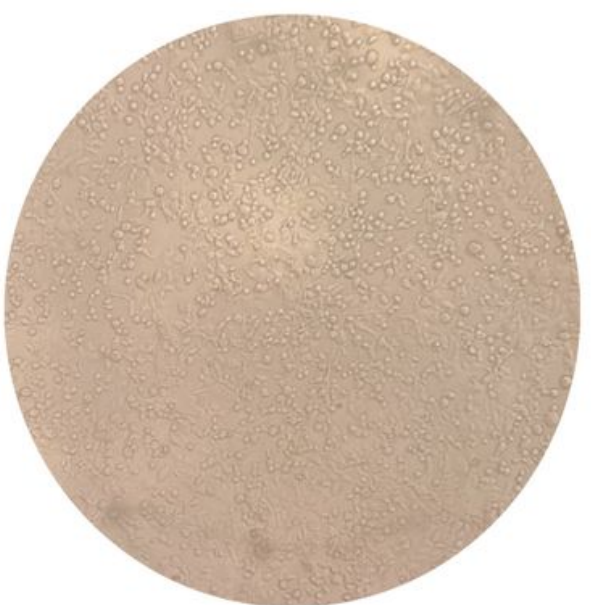

Control

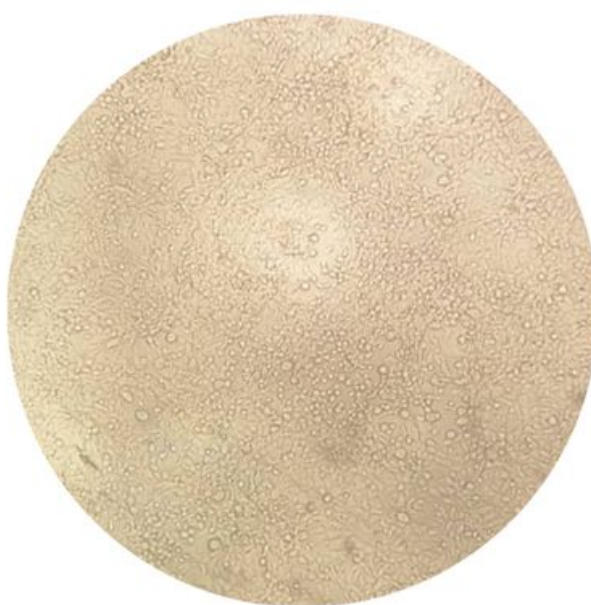

Pre incubation

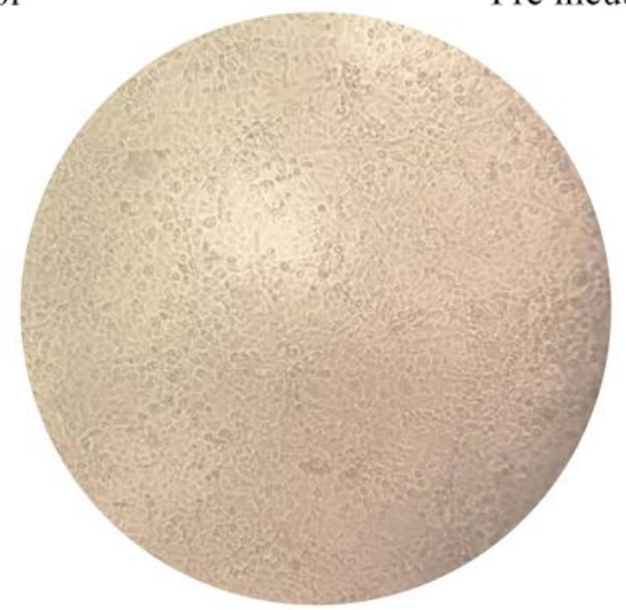

Post infection

\section{Figure 4}

Microscopy assay of infected cells, which were treated by NF-CS-ZnO nano-hybrid in three different experiment. 


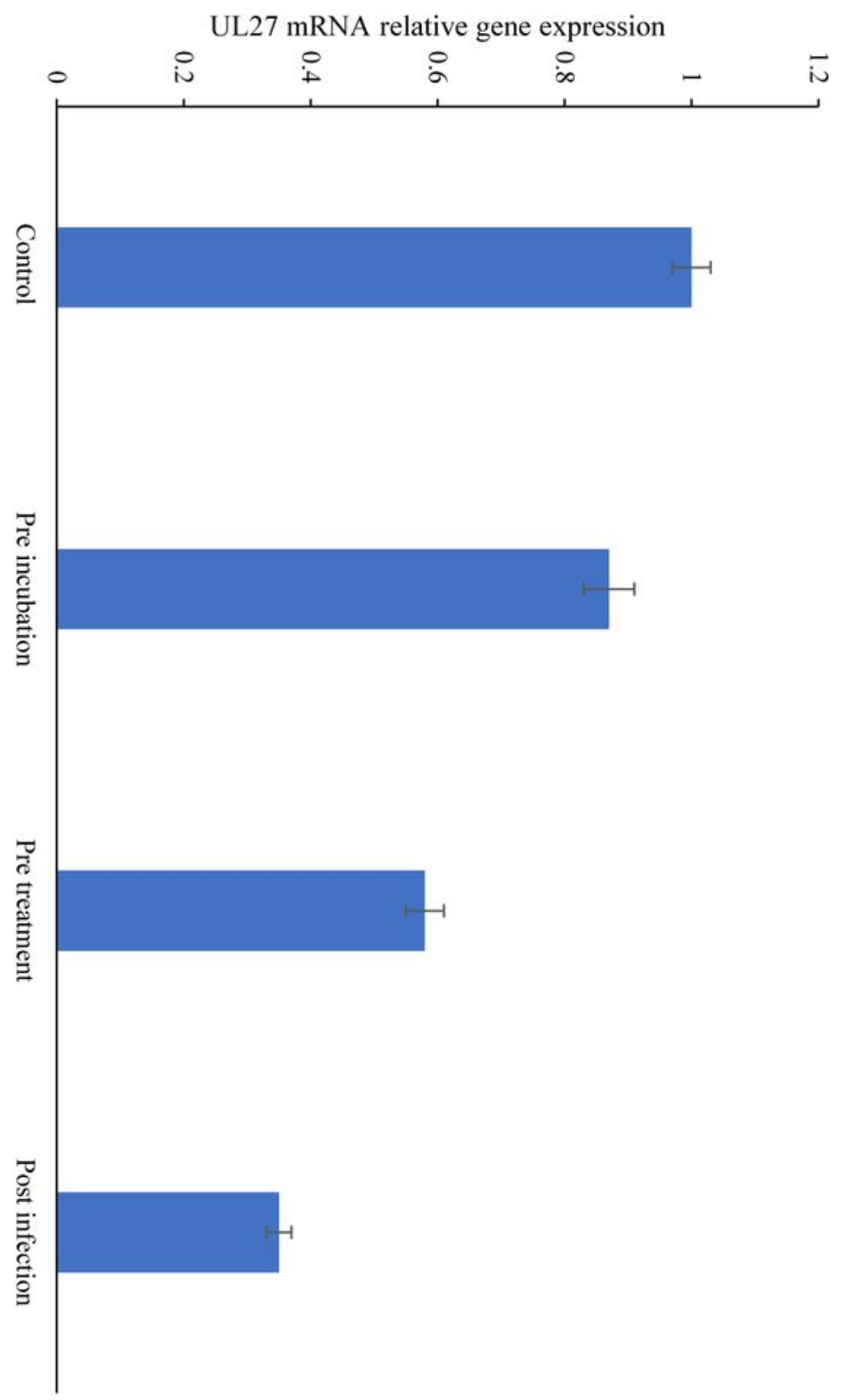

Figure 5

NF-CS-ZnO nano-hybrid significantly reduced the expression gene of UL27 in HSV-1 infected cells in post infection and pretreatment experiment.

\section{Supplementary Files}


This is a list of supplementary files associated with this preprint. Click to download.

- GraphicalAbstract.jpg 